\title{
Adaptor Signaling Protein
}

National Cancer Institute

\section{Source}

National Cancer Institute. Adaptor Signaling Protein. NCI Thesaurus. Code C26231.

A class of signaling pathway proteins that function to mediate the coupling of multiple cell surface receptors to downstream signaling pathways in the regulation of various cellular functions. (from Oncogene 2001;20:6315-21) 